\title{
デンプン食品中の水の移動を支配する要因
}

\author{
渡辺尚彦
}

国立大学法人東京海洋大学海洋科学部海洋食品科学科

\section{The Factor Which Governs Water Migration in Starchy Foods}

\author{
Hisahiko WATANABE \\ Department of Food Science and Technology, Tokyo University of Marine Science and Technology \\ National University Corporation, Konan 4, Minato, Tokyo 108-8477
}

\begin{abstract}
By the use of MRI, we clearly showed that starchy food has a complicated water content profile during cooking, a profile which is hard to be described by Fickian diffusion equation. In the search for the missing factor which governs the behavior of water absorption characteristic of starch, we come to the conclusion as follows: (1) There exists some confusion in the discussions of the published papers in terms of the usage of the word "gelatinization". (2) The gelatinization reaction of starch should be understood in terms of "terminal extent of gelatinization". (3) The information on the terminal extent of gelatinization as a function of temperature and water content at heat-treatment is of most importance. (4) The factor which governs the water migration in starchy food is "ceiling water content" which is the potential maximum of water holding capacity that a starchy food has. Fickian diffusion equation is applicable on a system that is homogeneous in terms of ceiling water content. We proposed Water Demand Model which has a potential to be applicable on a system that is inhomogeneous in terms of ceiling water content.
\end{abstract}

Key words: starch, water, diffusion, gelatinization, cooking, non-Fickian, MRI, ceiling water content, terminal extent of gelatinization, water demand

\section{1.はじめに}

魚や肉のように生でも食べられるものを加熱して食べ る場合もありますが，デンプン食品の場合は，ヒトは生 のデンプンを消化できませんので水と熱を加えてデンプ ンを糊化させて消化できる形にしないといけません。こ の過程がデンプン食品の加熱加工・調理の第一義です. 加熱加工・調理はデンプンを消化できるようにするだけ でなく食品を打いしくする過程でもあります，とくに米 飯や麺の場合はおいしさが食感（テクスチャ）に大きく 依存していますからおいしさと調理法が密接に結びつき ます。この重要な過程に取り扱いの難しいものを含んで います．科学的に未解明であり，そのためか炊飯や麺の 取り扱いには名人技がまだいろいろあります[註 1].

取り扱いが難しいと申しましたが，デンプン食品をあ まり知らない人は難しいとは思っておりません。「ご飯 なんて誰でも上手に炊けるよ。何が難しいものか.」と

(受付 2004 年 8 月 17 日, 受理 2004 年 8 H 24 月)

干 108-8477 東京都港区港南 4 丁 1 番 7

Fax: 03-5463-0497, E-mail: hisahiko@s.kaiyodai.ac.jp
いう訳です。

実は私もそう思っていた一人です。デンプン食品中の 水の移動の難しさが分かる前は、デンプン食品中の水分 移動も分子拡散係数が分からないのであり，それが分か ればそれなりにシミュレーションができるようになるだ ろうと思っておりました。

\section{2. 拡 散 係 数}

食品工学では熱や物質（水）の移動を取り扱います. 基本的な法則に基づいて温度分布や濃度分布を計算しょ うとすると物性值が必要になります。このとき熱に関す る物性值はハンドブックでどうにか見つかるのですが水 分分布を計算するのに必要な拡散係数や分配係数になる と何も見つからないので途方にくれると言う経験をされ た方が多いのではないでしょうか，拡散係数に関する情 報が少ないのは，拡散係数の測定が難しいことと，たと え測定しても試料の状態（拡散する媒体の構造）に依存 するので一般性をもった值として発表しにくいという事 情があります。 
食品中の水の应散係数の実測例として報告されるもの は乾燥実験に打ける重量変化から得られるものが多いで す。この場合，水分分布と重量变化を結び付けている数 学モデルの適不適が問題になるとともに，拡散係数の含 水率依存性が求め難く、できた場合も試料表面と内部と の含水率の差異を考慮することはできません。

磁場勾配 NMR 法による拡散係数測定はこれらの問題 をクリアーする便利な測定法です。我々は磁場勾配 NMR 法によりデンプン・水系における水の拡散係数を 系統的に測定しました。デンプンは糊化しないと水を保 持する能力に限界があり（33\%程度），糊化するとさら に水を吸えるようになります。糊化すると同じ含水率で は应散係数が低下しますが, 含水率が高くなると搪散係 数は上昇します。そうなると糊化度の程度によって拡散 係数の温度, 含水率依存性が変化することになり複雑に なります，そこで，未糊化の場合と十分糊化した場合と の 2 つの場合に分けてデンプン・水系の拡散係数の温 度，含水率依存性を定式化しました[1a, 1b]. [註 2, 3]

$$
\begin{aligned}
& D_{\text {non }}=D_{\text {free }} 0.127(w-0.33) \exp (778 / T) \\
& D_{\text {full }}=D_{\text {free }}(1.31 w-0.486) \\
& D_{\text {free }}=0.0232 \exp (-2070 / T) \\
& T ; \text { 温度 }[\mathrm{K}], w ; \text { 含水率 }[\mathrm{g} \text { water } / \mathrm{g} \text { sample }]
\end{aligned}
$$

\section{MRI（磁気共鳴画像法）}

最近は大きな病院には MRI という検査装置がありま すが、これはヒトの全身を磁石の中心にある穴（ボア） に挿入して測定するものです。このボア径を小さくして照 射する電磁波強度を大きくしたものが NMR Microscope として 1980 年代に市販されました。 NMRで画像を取 るにはシグナルの元であるプロトンの位置情報を知る必 要があります。磁場勾配をかけることにより位置情報を 周波数情報に変換（encode）できると言うのがMRIの 基礎原理ですが，拡散係数を測定するのも位置情報を同 じ手法で検出するので，磁場勾配 NMR と MRI とは共 通部分が多いのです[註 4 ].

MRI によって画像を撮ってみると，魚肉はきれいな 画像が撮れ，大豆[15]だと水を吸っていく様子がよく撮 れましたが，生のスパゲッテイですと水をたっぷり吸わ せたものの画像すら全く撮れないことがわかり驚きまし た。それでデンプン食品の画像をとるのは諦めていたの ですが，デンプンは加熱すると画像が取れることが後で 分かってきました．未糊化デンプンの NMR 緩和時間が とても短くて, 我々の使う装置の標㔼のデータ採取プロ グラムでは画像にならないのが原因で，デンプンを加熱 すると緩和時間が延びて測定できるようになるのです.

加熱すればなんとか測れそうだとわかった頃に「NMR 装置の中で米を炊いてリアルタイムで炊飯途上の含水率 分布を測定したい」という強い希望が寄せられ（竹内繁
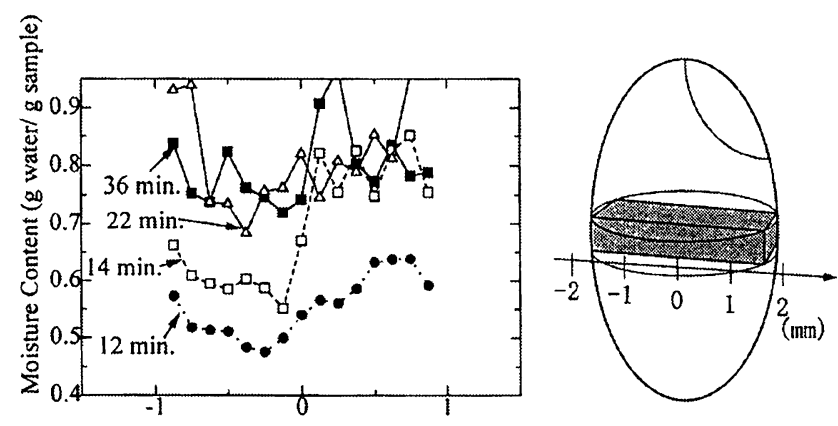

Position (mm)

Fig. 1 Water content profile plotted against the distance from the center in a rice grain during cooking. The profile was obtained through real time observation via MRI $\mathrm{T}_{2}$ measurement.

樹: 当時三菱電機（株）中央研究所）, 共同研究するこ とになりました。いろいろ苦労はありましたが、プロー ブへッドに組み込んだセラミックヒータで加熱した窒素 ガスを米と水の入ったガラスの試験管に吹き付けて加熱 する方式で炊飯し，米 1 粒を $\mathrm{y}$ 軸および $\mathrm{z}$ 軸について仮 想的にスライスした角柱状の試料についての $\mathrm{x}$ 軸 1 次元 画像をエコータイムを変えて測定し， $\mathrm{x}$ 軸の各位置での 緩和時間を測定することで, 炊飯途上の米 1 粒中の水分 分布を測定する研究ができました $[4,5]$.

測ってみますと, Fickの拡散方程式からは考えられ ない凄く不思議な水分分布 (Fig.1) をすることが分か りました. 水分分布の形はCase II diffusion[6,7]と呼 ばれるものに似ているように見えました。同じ頃，英国 Cambridge 大の Fryer · Stapley らは小麦 1 粒の内部の 水分分布がボイル途中でどう変化するかを MRI で測定 する研究[8]をしており，やはり Case II だということ を言っています。しかし、私たちの研究も彼らの研究も 「無理やりやっと測った」という状態でした。これは穀物 の粒が複雑な形をしていることとサイズが小さいというこ とが原因でした，これでは，水分分布が異常らしいという ことは確かでも，正確にどのようにおかしいのかを主張し 難く, 正確な測定無しでは先に進めないと思いました.

そこで，起きている現象をしっかり把握するためには 本物の食品にこだわるのではなく, 測定に有利なモデル 食品を使用しようと考え, 小麦粉ドウを平板状にしたも のを熱水で煮るときにドウ内部の水分分布がどう変わる かを MRIで測定しました[9]. MRI 画像から換算した 水分分布をFig. 2 に示します.

ボイルを 60 分間続けた後の水分分布はこの太い線で 示したように 3 つのフラットな部分をもつ不思議な形を していました。この分布は水の搪散係数の濃度依存性を 考慮したところでとても従来の Fick の拡散方程式では 記述できない. デンプン食品中の水の移動に関しては何 か重要な要因が分かっていないのではないか? それを探 そうということにしました。 


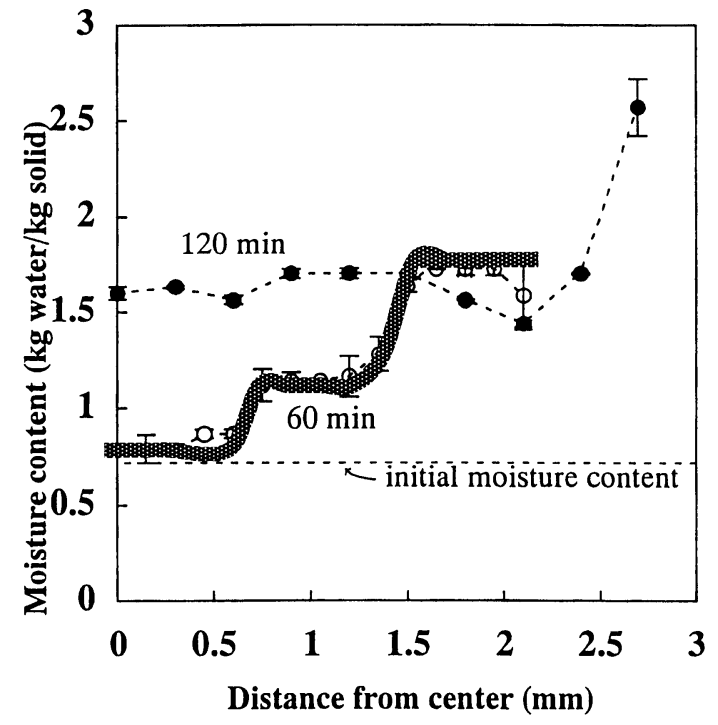

Fig. 2 Water content profile plotted against the distance from the center in a slab of wheat flour dough during cooking.

\section{4. デンプン食品中の水分移動を支配する因子}

そこで我々もデンプンの研究を始めました，国内外の 諸先輩が永年研究されている分野へすごく遅れての参人 でしたが，幸い，目指すものがはっきりしていたため従 来と異なる視点をもって研究できたことおよびMRI と いう道具のおかげで, 従来見過ごされていたものの中に 重要因子を見つけることができました[10a]。その結果 は次の 4 つに䌕めることができます.

A) 糊化という用語に混乱あり：水の移動はデンプンの 糊化が決定的に大きな役割を果たすのですが，まず，糊 化という言葉そのものが問題です．糊化に関する研究は それまでに数多くなされていました。しかし用語の混乱 があって, 研究結果の discussionに色々と誤りがあり そうだということがわかりました[2]，吸水に関して重 要なのは糊化と呼ばれる一連の event (事象) の中の初 期の event のみであり, 中期以降の event であるレオロ ジカルな糊化現象と区別して考える必要があります。

B) 終末糊化度 : 終末糊化度という概念を導入しまし た. Fig. 3 で縦軸は糊化度, 横軸は加熱処理時間を表 しますが, 糊化はどの温度でも 1 分以内に終了するので すが，糊化度は必ずしも $100 \%$ に達せず，ある一定の糊 化度で止まる。これを終末糊化度と呼びます。つまり， 糊化は速くて遅いのであって, 平均化した糊化速度を用 いた（糊化）反応モデルは終末糊化度が小さい状況では 意味をなさなくなります。

C) 水が無いと糊化しない：Fig. 4 は, 終末糊化度が デンプン食品を熱処理するときの含水率と温度に依存す る様子を示したものです[10b]。縦軸は終末糊化度, 横 軸は熱処理温度です．パラメータは熱処理をするときの 含水率です。この太い線の部分は十分に水がある条件で

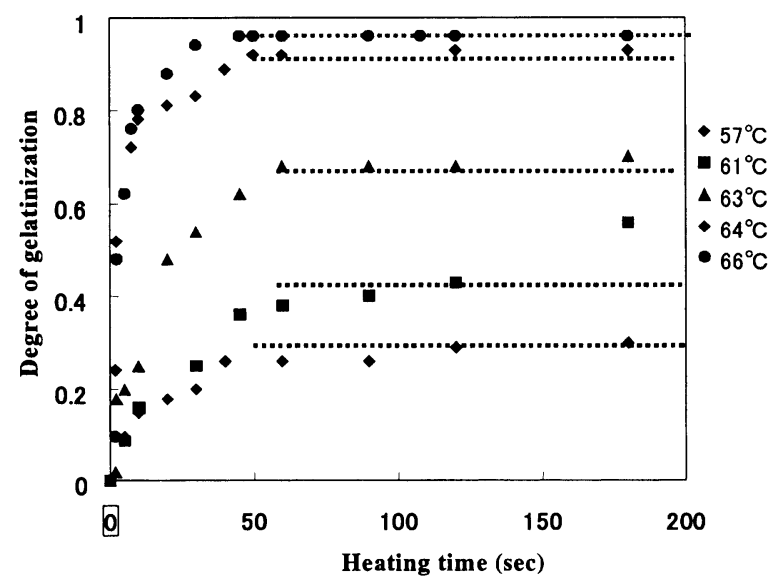

Fig. 3 Progress of the extent of gelatinization as observed via birefringence in starch granule/water systems during heattreatment. Each of the system reaches a terminal extent of gelatinization that is governed by temperature (in excess water condition)

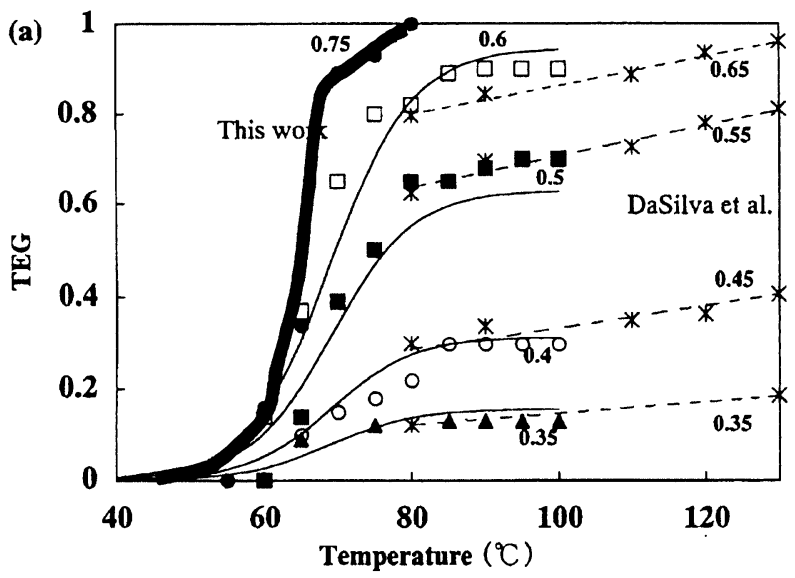

Fig. 4 Terminal extent of gelatinization (TEG) plotted as a function of temperature and water content (wet basis) at its heat-treatment.

の熱処理を意味しますが，従来の糊化の研究はほとんど がこの太線部分, excess waterの条件での研究で, 水 が少ない条件の研究が少なくて困りました。

D) 天井含水率：デンプン食品のもつ水保持能力を天井 含水率 $\left(m_{\mathrm{clg}}\right)$ と名付け, 天井含水率が水の移動を支配 していると考えました． $m_{\mathrm{clg}}$ はデンプンの（終末）糊化 度の関数です.

\section{Water Demand Model}

デンプン食品中の水分移動を支配するのは天井含水率 であると考えました。食品中の天井含水率（終末糊化度 の関数）が均一であればその食品は均一相と考えてよく Fickの搪散方程式は適用可能です。しかし，食品中で 天井含水率が違っている（分布している）場合は異相系 (多重異相系）であり Fickの拡散方程式は適用できま 
せん．異相系としての取り扱い方として Water Demand （WD）モデルを提唱しました[11].

$$
W D=m_{\text {clg }}(x)-m(x)
$$

まず, 天井含水率と実際の含水率の差をWater Demand と定義します。通常, 水の移動の速さは含水率の勾配に 比例すると考える（Fickの法則）のですが，これに代 わって水の移動の速さはWDの勾配に比例すると仮定 しました。

$$
j=D \rho_{\text {solid }} \frac{\partial W D}{\partial x}
$$

この方程式を使うと色々変わった水分分布の変化を表現 できます。例えば，Fig．5で，縦軸が含水率，横軸が 場所ですが，左端が中心で右端がボイルしている表面側 です。表面の含水率が高くて, その高い部分が内部に進 行していく．ここに含水率一定の部分ができる.内部で は含水率が急に落ちるところがあって中心は未糊化であ る。この糊化した部分のフロントが進行するタイプの水

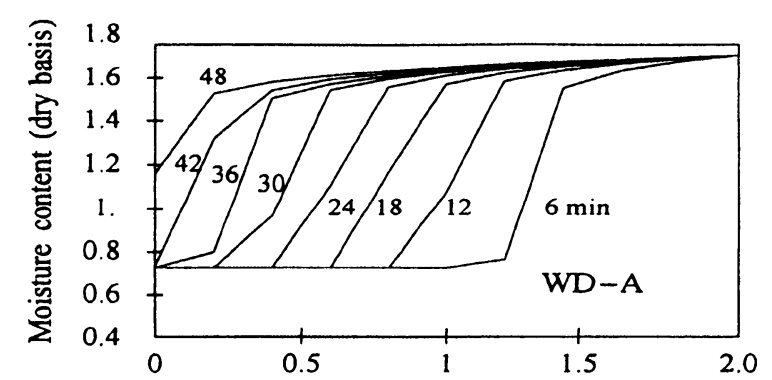

(a)

Distance from center $(\mathrm{mm})$
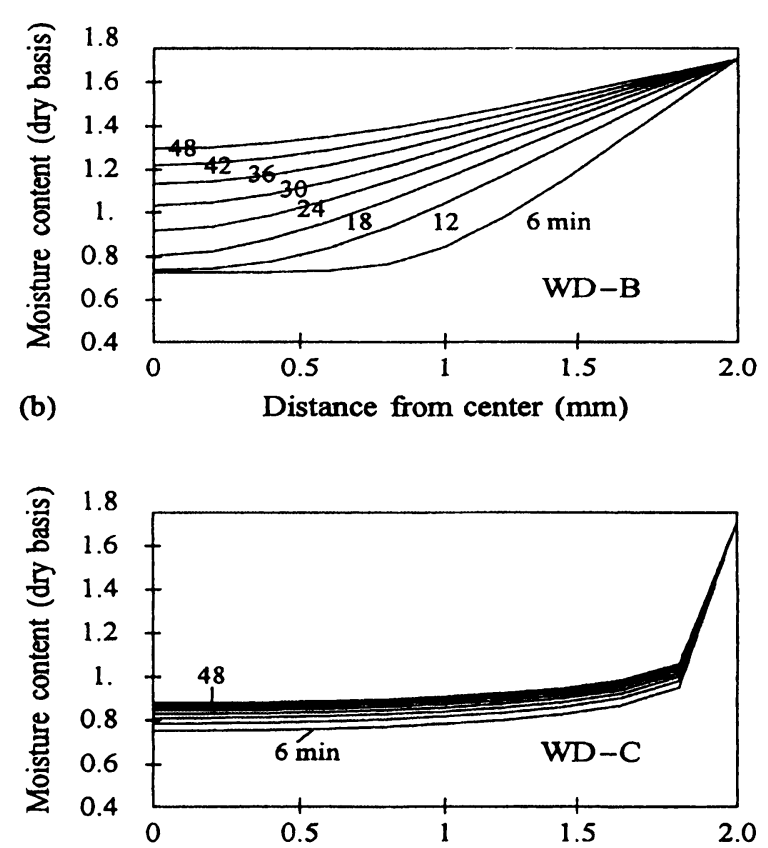

(c)

Distance from center $(\mathrm{mm})$

Fig. 5 Water content profile in a slab of wheat flour dough calculated by Water Demand Model. The slab is supposed to be boiled at $100^{\circ} \mathrm{C}$. The profiles, a, b, c correspond to the use of Water Demand curves WD-A, WD-B, WD-C in Fig. 6, respectively.
分分布はWDとして Fig. 6 の WD-A 形のものを選ぶ と計算で表現できます。

これに対して, Fickの法則に近い含水率分布を表現 するには, 直線型の WD（Fig. 6, WD-8）を選べばい いのです．WD モデルはその中に Fickの拡散方程式を 内蔵しているので, Fickの拡散方程式の拡張版とみな

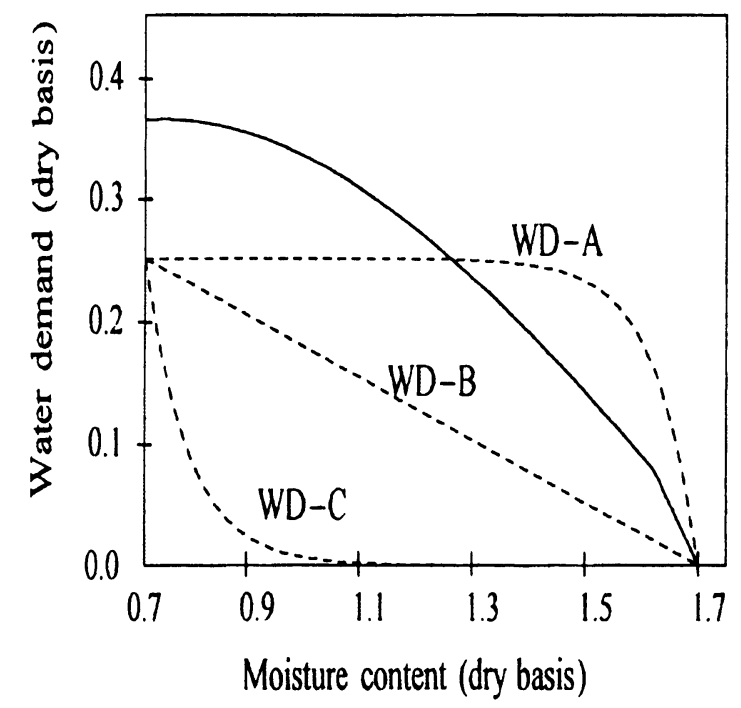

Fig. 6 Three typical shape of Water Demand curves as a function of water content at its heat-treatment. The temperature of heat-treatment is supposed to be constant.
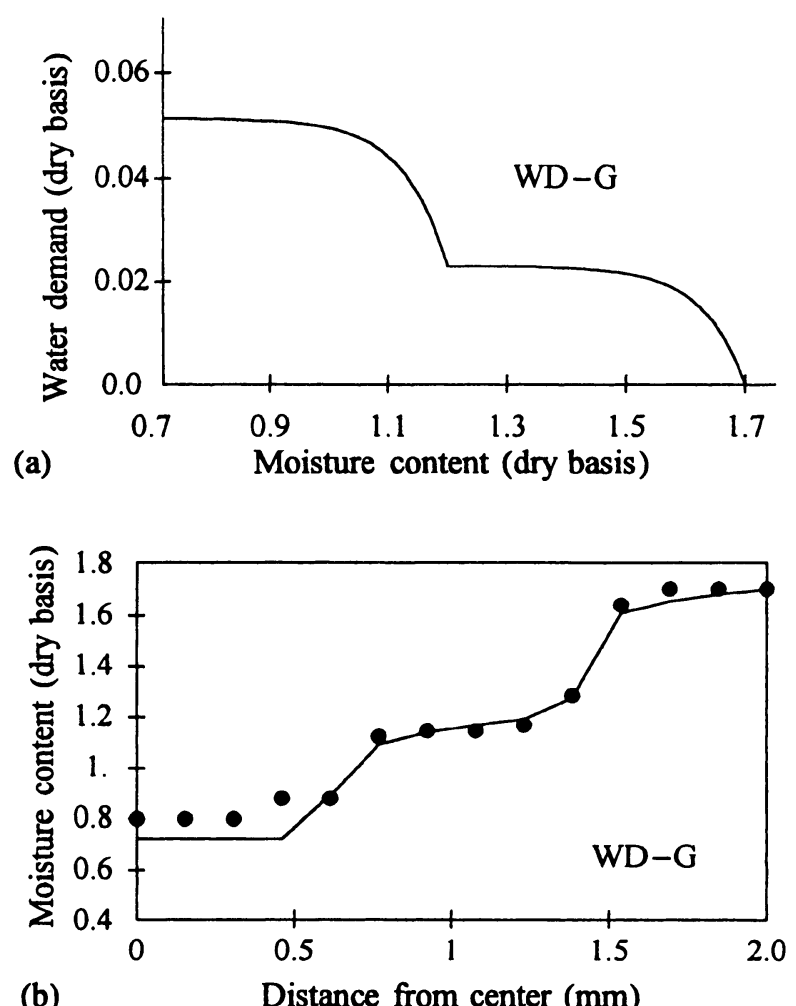

Fig. 7 Applying the curve Fig. 7a as a water demand results in the complicated water content profile (Fig. $7 \mathrm{~b}$ ) in a flour dough slab during boiling at $100^{\circ} \mathrm{C}$, when the water content is calculated using Water Demand Model. 
せます.さらに，WD として Fig. 7 (a)のような 2 段構 造のものを使うと Fig. 2 に示したフラットな部分が 3 つある不思議な水分分布（Fig. 7 (b)）も表現できる ことが分かりました[11].

\section{6. 小麦粉ドウ中の水の含水率勾配に 逆行する移動 [註 5]}

Water Demand モデル がデンプン食品中での特色あ る水分分布を記述できる可能性を有するものであること を示しましたが, Water Demand モデルは考方方が易 しいモデルなので新たな発想によって実験の設計しよう とするうえでも有用です，我々は，デンプン食品中で水 を水分勾配に逆らって水の少ない方から多いほうへ移動 させる実験が可能であることを思いつきました[12a].

小麦粉のドウを作ってベークライトの枠に押し込んで 平板状にします。これを熱に強いプラスチックフィルム で包んでシールし，水分が逃げないようにします。この 平板の右側の面を氷水で $0{ }^{\circ} \mathrm{C} に$ 冷やし同時に左側の面を $95{ }^{\circ} \mathrm{C}$ 加熱します. すると, 数分で定常状態になり直線 の温度分布になります。，小麦デンプンの糊化温度は $55{ }^{\circ} \mathrm{C}$ 前後なので右側半分は糊化が起きず未糊化のまま ですが, 左半分は $55{ }^{\circ} \mathrm{C} よ り$ 高温になり糊化が進みます。

糊化の程度は温度に依存し左に行くほど終末糊化度は 高くなるでしょう。この熱処理を温度勾配熱処理と呼び ます. 10 分程度の熱処理後に, 試料全体を室温に下げ て乾燥を防ぎながら放置しておきます。すると最初均一 だった平板内の水はどう動くでしょうか？

どんなことが起きるのか簡単なモデルで考えて見ます. 未糊化の 2 つのドウ平板 A と B があるとします（Fig. 8). $m_{\mathrm{clg}}$ は天井含水率です. $m$ は実際の含水率です。ここ で， A だけ例えば $100{ }^{\circ} \mathrm{C} に$ 加熱します。すると，糊化が 進んで $\mathrm{A}$ の天井含水率が上昇します。 $\mathrm{A}$ を水水で冷や して室温に戻した後で、A と B とを接触させます。水は 動くでしょうか?

WD modelでは水はWD の小さい右から大きい左へ 水が動くと予想します。温度勾配熱处理した小麦ドウ内 部では Fig. 9 のように天井含水率が左が高くなってい

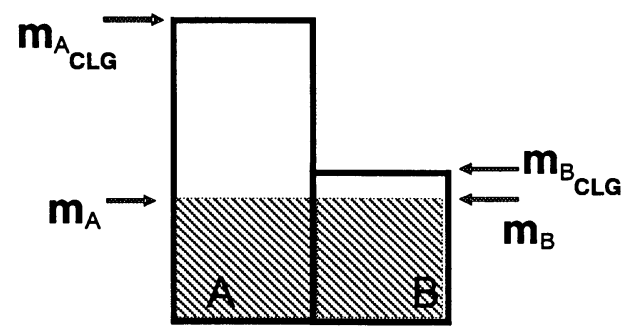

Fig. 8 What may happen when a couple of flour dough layers is made in contact after one of which is heat-treated to raise its ceiling water content.

\section{Ceiling water content}

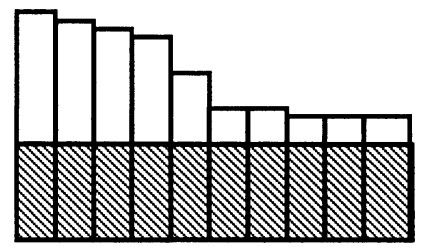

Position

Fig. 9 Expected arrangement of ceiling water content in a wheat flour dough slab which is temperature-gradient heat treated.

\section{Before}

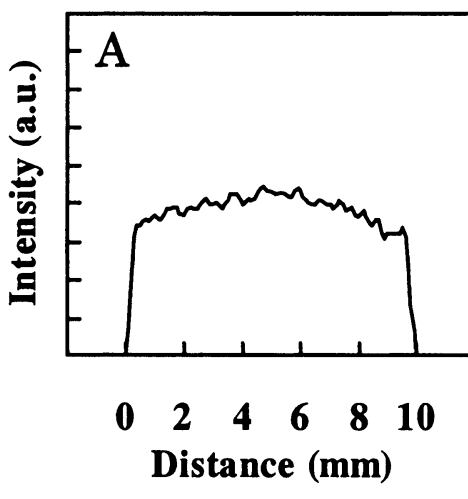

1 day after

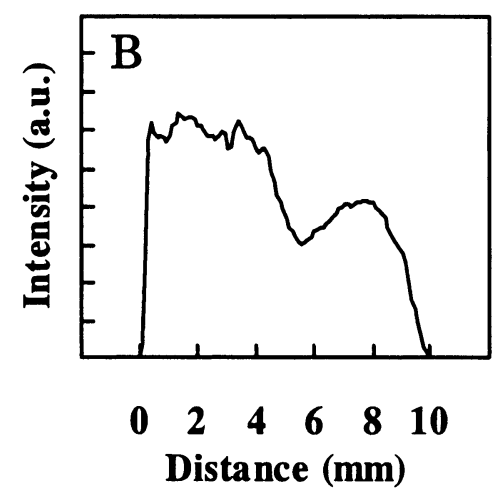

3 days after

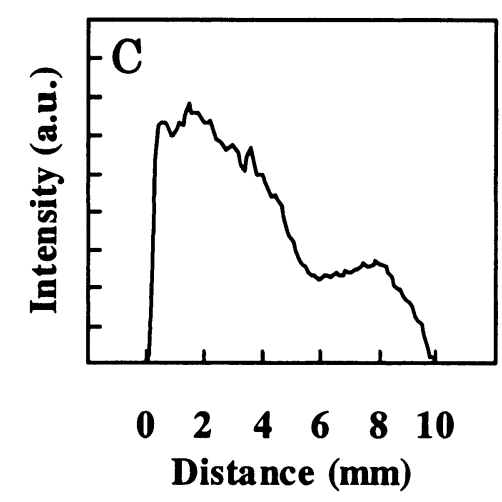

Fig. 10 MRI intensity profile against the position in a wheat flour dough slab, before and after the temperature-gradient heat treatment. 
るので, 水は右から左へ動くでしょう。

Fig. 10 は実験結果です。温度勾配熱処理した小麦粉 ドゥ平板の厚さ方向についての MRIのシグナル強度を 釉軸に，横軸は小麦粉ドウ平板の加熱表面からの距離を 示します．左側が加熱した面，右側が氷水で泠やした面 です。加熱処理前は A の通り大体フラットですが，1日 後にはBのような分布になり，明らかに水が右から左 に動いています，3日たつと，さらに水は左に動きます。 これは水が含水率の勾配に逆らって動いていることを示 します[12b]

MRI シグナル分布は緩和時間の影響を受けて水分分 布が誇張されて差違が大きくでますが，水の移動方向は はっきり見られます。MRIシグナルを緩和時間の影響 を考慮してキャリブレーションして含水率分布（省略） が得られます.

\section{7. 多重異相系での分配平衡モデル[註 5]}

次にこのような水分分布の変化をシミュレーションす ることを考えましょう。話を簡単にするために 2 つの小 麦粉ドウ平板で考えます（Fig．8）。左のドウが加熱さ れて天井含水率が上昇すると水が右から左に動くだろう ことは先に示しました。では，水分移動はどこで停止す るでしょうか？

WD モデルではWD が等しくなるところで止まると考え ます。しかし，この考え方は 2 つ平板中の含水率が小さ いときには明らかに矛盾をきたすことがわかります。そこ で、いったんWD モデルから離れて別の考えをとります。

通常、熱力学で物質の濃度平衡を扱うときはA，B 2 つの相でのケミカルポテンシアルが等しくなったところ で停止すると考えます。

$$
\begin{aligned}
& \mu_{A}=\mu_{A}{ }^{0}+R T 1 \mathrm{n} m_{A}=\mu_{B}=\mu_{B}{ }^{0}+R T 1 \mathrm{n} m_{B} \\
& K=m_{A} / m_{B}=\exp \left[\left\{\mu_{B}{ }^{0}-\mu_{A}{ }^{0}\right\} / R T\right]
\end{aligned}
$$

このときの A，B 両相での含水率の比，つまり分配係数 $K$ は温度の関数になりますが，含水率 $m$ には無関係な ことが分かります。そこで，分配係数を天井含水率の比 で決めてよいことが分かります。

さて，天井含水率の異なる A，B 2 つの相が接触した ときの水分分布の経時変化を計算する仕方ですが， 2 相 の界面では瞬間的に分配平衡が成立すると考え，他方， 各々の相の内部では Fick の拡散方程式に従って水が移 動すると考えます (Fig. 11).

この考え方によって計算するために，まず小麦粉ドウ の天井含水率を測定しました[16]。そして，温度勾配熱 処理をした小麦粉ドウの平板内部を厚さ方向に 10 枚の 仮想的な薄い層に分割したと考えたときの各境界面での 天井含水率の比を計算し分配係数としました。この分配 係数を用いてシミュレーションした結果が，Fig. 12 の 通りです。水の拡散係数としては $1.0 \times 10^{-10} \mathrm{~m}^{2} / \mathrm{s}$ を用

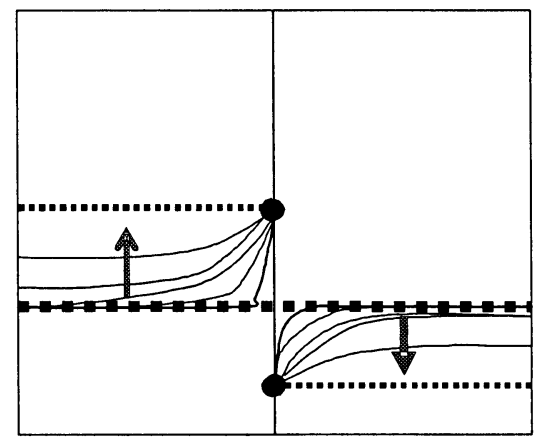

Fig.11 At the boundary between the two layers made in contact, instantaneous equilibrium in water content is assumed. Inside the layer, Fickian diffusion rules.

いました， 2 時間後にドウ平板の中央部に隆起するとこ ろと陥没するところが波のように現れ，24 時間後には しっかり右から左へと水が移動した分布になります。

3 日後の水分分布をこのシミュレーションによる計算 結果と実験結果とを重ねて書く（Fig. 13）とよく一致し ていることが分かります[13]。これらの結果から，糊化 度が変化する系に打ける水分移動は天井含水率に基づく 分配係数を導入した多重異相系モデルで説明できること が分かります。

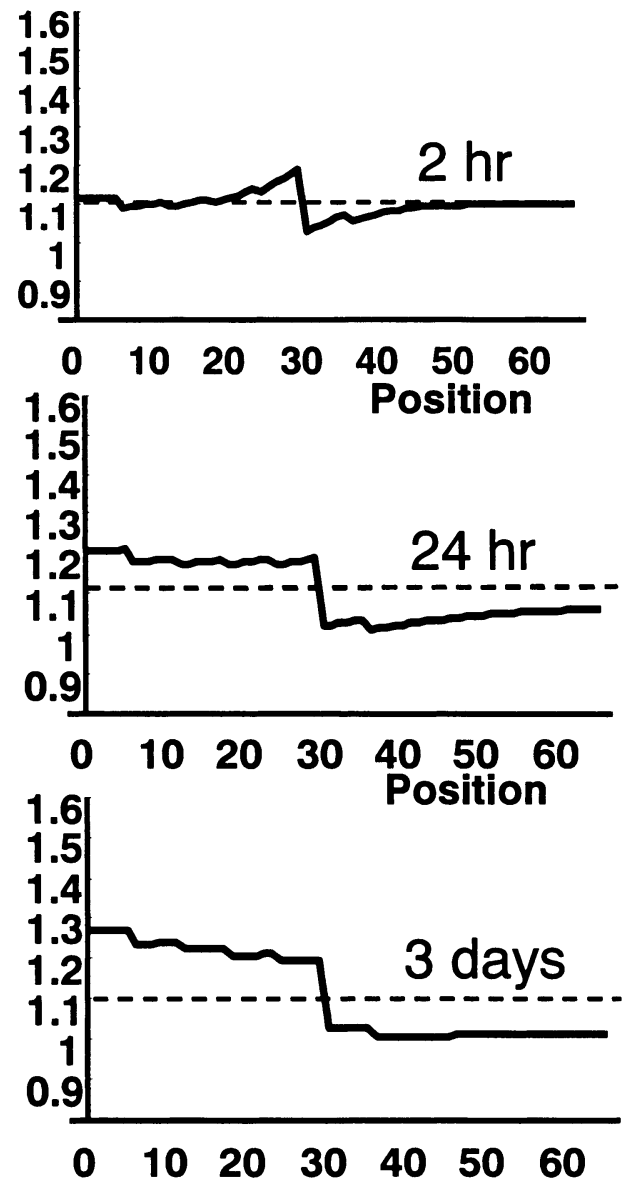

Fig.12 Simulated water content profile across the slab $2 \mathrm{hr}, 24 \mathrm{hr}$ and 3days after heat-treatment. The dash line shows the initial water content. 


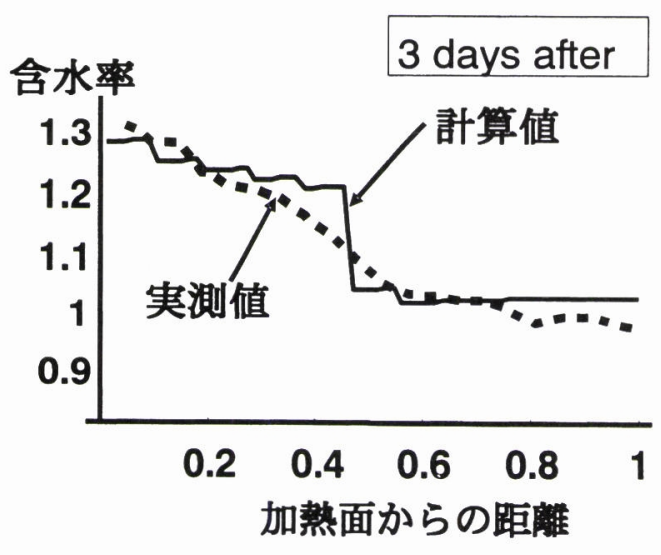

Fig. 13 Water content profile comparison between measured and calculated for the dough slab 3 days after the gradienttemperature heat treatment.

\section{8. 実用的な開発研究への展開}

以上, 学術面に扎いて, デンプン食品中の水分移動の 不思議の解明に些かなりとも貢献できたのではないかと 考えて打りますが，こ扎を産業界への貢献とするには Water Demand モデルをもとに発明をして特許をとら なくてはなりません. 幸い, 麺や米の中心部だけを糊化 して表面部分は未糊化のままに保つことによる，高品質
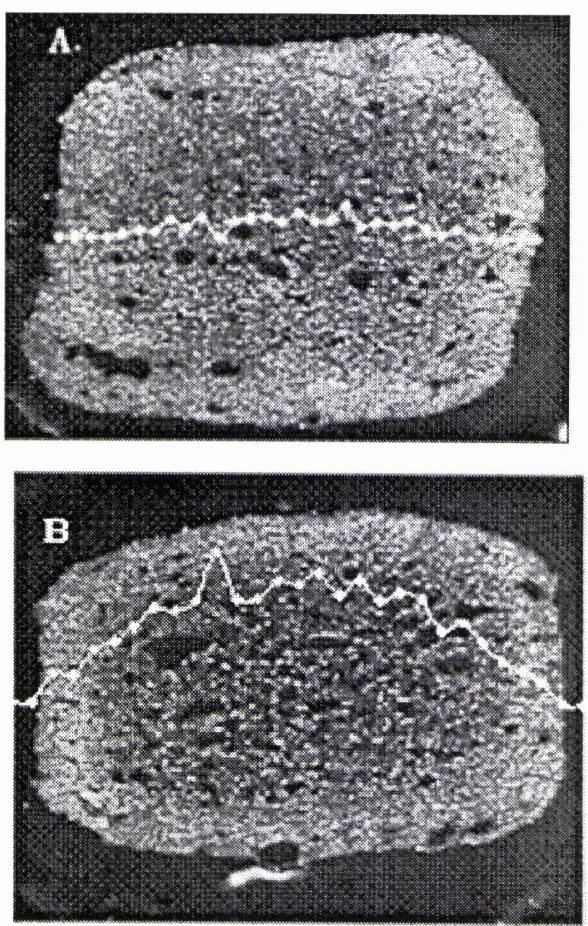

Fig. 14 Polarizing microscope images of cross section of udon. Non-treated dry udon (A) is bright (meaning un-gelatinized) all over the region, while the processed udon (B) is bright only at the periphery and dark (partly gelatinized) in the core. The calculated TEG is also compared with the cross-section picture of the udon.
早茹で缅[17] あるいは高品質早炊き米の製造につなが る発明をすることができ（Fig. 14），科学技術振興事業 団（JST）から特許出願[18]しました。

さらに炊飯時に必ず生じるクラックが米粒内の水分移 動に大きな役割を演じていること[19]は明白でして，実 用上は重要なポイントです。クラックや割机米の効果ま で取り込んだ实用モデルを考える段階にやっとたどり着 いたところと言えましょう。

註釈

註 1）本稿は「デンプン食品中の水の移動を支配する要 因」と題していますが，水分移動がとくに重要問題にな るのは，デンプン食品素材を加熱加工・調理する際に水 と熱の両方を同時に加える必要がある場合，具体的には 米を炊くあるいは湎を茹でるという場合に限られるかも しれません。

デンプン食品は人類の主要食品であり永い歴史に培わ れた多彩な食文化の主役を担ってきました。デンプン食 品は款類（コメ，ムギ，トウモロコシ）とイモ類であり これをそのまま食する場合と粉にして食する場合に分け られますが，加工・調理の技術から見ると食品（物体） の外からの水の移動を必要とするか否かで大きく異なり ます。小麦・米・トウモロコシの粉に水を加えてそれを 焼く場合は加える水が少ない場合（パン・クッキー・ク ラッカー・せんべい) も多い場合（パンケーキ・打好み 焼き類）も，水はデンプンのすぐ近くに配置されている ので加熱だけが問題になります。また，亿モ類（生）は 糊化に必要な水を含んでいますので焼く場合も煮る場合 も加熱による糊化だけが問題で水分移動は問題にならな いのです。これに対して米や麦の㳵粒を煮る（蒸す）場 合や粉食であっても湎を茹でるばあいは食品（物体）の外 部から内部へ水を移動させないと十分に糊化が進行しな い。この過程が実は大変難しいものを含んでいるのです。 註 2）後に，この磁場勾配 NMR によるデンプン・水系 での水の拡散係数の含水率依任性を利用して終末糊化 度を測定しました[2]。また, 普通はデンプン・水系を マクロに捉えて「含水率」を一つ当て嵌めていますが, デンプンは糊化しやすい顆粒と糊化しにくい顆粒との混 合物であって糊化しやすい顆粒が先に糊化すると未糊化 にとどまっている顆粒の周りから水を奪い取るために局 所的に含水率に差異が生じます。そこで, 磁場公配 N M $\mathrm{R}$ 法で得られる実験結果の曲線を 2 本の線に分解して. 局所的に糊化した部分と未糊化の部分とに別の拡散係数 を割り当て，局所含水率をある程度まで推定できること を示しました[3]。

註 3) 磁場勾配 NMR 法で得られる水の分子桩散係数が 水分分布の变化から得られる拡散係数よりずっと大きな 值になることがしばしばあります。それぞれの方法に原 
因がありそうですが未解明のまま残されています。 註 4) 私は大学院の学生のときに磁場勾配 NMR で拡散 係数を測定した論文を読んでとても興味をもちました。 そのころは日本に磁場勾配 NMR は 1 台もないといわ れ，将来自分で使えるようになるとは思っていませんで したが，論文が読めるようにと Farrar \& Beckerの教 科書 [14]で磁場勾配 NMRの勉強だけはしておきまし た。ところが，幸運なことに，就職した東京水産大学で NMR を新たに購入する機会に恵まれ，磁場勾配を 3 方 向に架け画像を取る装置が使えるようになりました。西 ドイッの Bruker 社が開発したばかりの取扱説明書も無 い最新のものでした．拡散係数を測定するプログラムは 付いておらず自分で開発しなくてはなりませんでした。 註 5） 6 節および 7 節については引用文献に示した発表 より後に得られた実験結果に基づいて記述しました。現 在，投稿中のため詳細な根拠はお示しできません.

\section{謝辞}

名誉ある日本食品工学会賞の受賞者に選考いただきま した幸運に恵まれ深く感謝いたします。授賞のみならず， 本研究を遂行できたこと自体が，多くの幸運にタイミン グよく出会えた結果であり，東京水産大学食品生産学科 食品プロセス工学研究室をはじめ関係の皆様のご支援ご 協力に深く感謝いたします。

\section{引用文献}

1a) Gomi, Y., Fukuoka, M., Takeuchi, S., Mihori, T., Watanabe, H.: Effect of temperature and moisture content on water diffusion coefficients in rice starch/water mixtures. Food Science \& Technology International, 2, 171-173 (1996).

1b) 福岡美香，渡辺尚彦：小麦デンプン・水系および小麦粉・ 水系に打ける水の拡散係数、日本食品工学会誌, 2 (1) 23-26 (2001).

2) Gomi, Y., Fukuoka, M., Mihori, T., Watanabe, H.: The rate of starch gelatinization as observed by PFG-NMR measurement of water diffusivity in rice starch/water mixtures. Journal of Food Engineering, 36, 359-369 (1998).

3) Watanabe, H., Fukuoka, M.: PFG-NMR applied to measure the difference in local moisture content between gelatinized and non-gelatinized region in a heated starch/water system. In "Starch, Advances in structure and function" (eds. Barsby, Donald, Frazier), pp.53-58, The Royal Society of Chemistry, UK. (2001).

4) Takeuchi, S., Fukuoka, M., Gomi, Y., Maeda, M., Watanabe, H.: An application of magnetic resonance imaging to the real time measurement of the change of moisture profile in a rice grain during boiling. Journal of Food Engineering, 33, 181-192 (1997).

5) Takeuchi, S., Maeda, M., Gomi, Y., Fukuoka, M., Watanabe, H.: The change of moisture distribution in a rice grain during boiling as observed by NMR imaging. Journal of Food Engineering, 33, 281-297 (1997).

6) Thomas, N.L., Windel, A.H.: A theory of case II diffusion, Polymer, 23, 529-542, (1982).

7) Wu, J. C., Peppas, N. A.: Modeling of penetrant diffusion in glassy polymers with an integral sorption Deborah number, Journal of Polymer Science: Part B: Polymer Physics, 31,1503-1518 (1993).

8) Stapley, A.G.F., Hyde, T. M., Gladden L. F. , Fryer, P.J.: NMR imaging of the wheat grain cooking process, Int. J. Food Sci. Tech, 32, 355-375 (1997).

9) Fukuoka, M., Mihori, T., Watanabe, H.: MRI observation and mathematical model simulation of water migration in wheat flour dough during boiling. Journal of Food Science, 65, 1343-1348 (2000).

10a）福岡美香, 渡辺尚彦：デンプン食品中の水分移動とその支 配要因，日本食品工学会第 2 回年次大会講演要旨集，p. 115 , 東京 (2001).

10b) Fukuoka, M., Ohta, K., Watanabe, H.: Determination of the terminal extent of starch gelatinization in a limited water system by DSC., Journal of Food Engineering, 53 (1): 39-42 (2002).

11) Watanabe, H., Fukuoka, M., Tomiya, A., Mihori, T.: A non-Fickian diffusion model for water migration in starchy food during cooking. Journal of Food Engineering, 49, 1-6 (2001).

12a）八幡淑子, 福岡美香, 渡辺尚彦：デンプン食品の調理（加 熱）過程に打ける水分移動に関する研究. 日本食品工学会 第 1 回年次大会講演要旨集, p.104, 東京 $(2000)$.

12b) 八幡淑子，福岡美香，渡辺尚彦：デンプン食品中に起きる アゲンストな水分移動の解明. 日本食品工学会第 2 回年次 大会講演要旨集, p.116, 滋賀 (2001).

13）八幡淑子 - 福岡美香 - 崎山高明 - 三堀友雄 - 渡辺尚彦：天 井含水率を用いた Water Demand Model によるデンプン 食品中の水分移動の記述，日本食品工学会 5 回年次大会講 演要旨集，p. 132，東京，(2004).

14) Farrar, T.C., Becker, E.D.: Pulse and Fourier Transform NMR, Academic Press (1971).

15) Fukuoka, M., Watanabe, H., Mihori, T., Shimada, S. Moisture diffusion in a dry soybean seed measured using pulsed-field-gradient NMR Journal of Food Engineering, 23, 533-541 (1994).

16）八幡淑子, 福岡美香, 渡辺尚彦：デンプン食品中の水分移 動を支配する天井含水率の測定. 日本食品工学会第 3 回年 次大会講演要旨集, p.119, 東京, (2002). 
17) Thammathongchat, S., Fukuoka, M., Watanabe, H. : An innovative noodle: gelatinized at the core, leaving the surface un-gelatinized, Journal of Food Engineering, submitted (2004).

18）渡辺尚彦，福岡美香：機能性を付与したデンプン食品およ びその製造方法, 特願 2003-332412, (2003).

19)篠田千冬, 福岡美香, 渡辺尚彦: 米飯粒内の糊化進行過程 の可視化, 日本調理学会誌，34 (4)，396-398 (2001).

\section{要旨}

デンプン食品を加熱加工・調理する過程で水分分布が Fick の拡散方程式では記述し難い複雑な挙動を示すこ とを磁気共鳴画像法により明確に示した。この原因を解
明するためにデンプン食品の吸水特性を支配する因子に ついて新しい視点から研究し次の結論を得た：(1) 糊化 という用語の使われ方による混乱がある (2) 糊化反応 を終末糊化度の視点で捉えるべき (3) 終末糊化度の含 水率・温度依存性の把握が大切 (4) デンプン食品中の 水分移動を支配するのは天井含水率（デンプン食品の水 保持能力）である。天井含水率（終末糊化度の関数） が均一であれば均一相であり Fick の拡散方程式は適用 可能である。しかし、食品中で天井含水率が分布してい る場合は多重異相系であり Fickの拡散方程式は適用で きない。多重異相系に適用可能なモデルとして Water Demand (WD) モデルを提唱した。さらにWD モデル を発想の道具として使い麺・米に新規な特性をもたせる 方法を発明した。 